\title{
THE SEA FLOOR ENVIRONMENT AND THE FISHERY OF EASTERN GEORGES BANK
}

The Influence of Geologic and Oceanographic Environmental Factors

on the Abundance and Distribution of Fisheries Resources of the Northeastern United States Continental Shelf

by

Page C. Valentine ${ }^{1}$ and R. Gregory Lough ${ }^{2}$

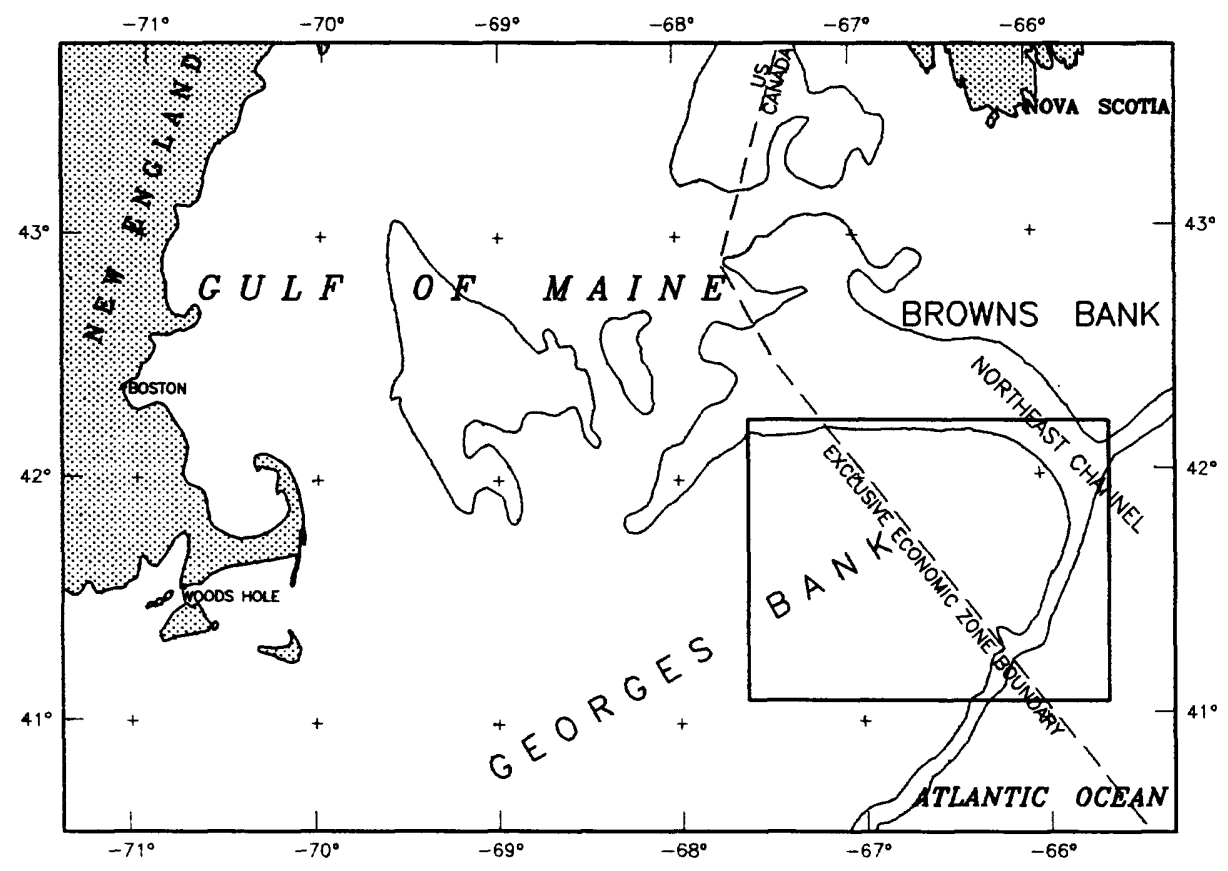

Open-File Report 91-439

This report is preliminary and has not been reviewed for conformity with U.S. Geological Survey editorial standards and stratigraphic nomenclature.

${ }^{1}$ U.S. Geological Survey, ${ }^{2}$ National Marine Fisheries Service, Woods Hole, MA 
Page C. Valentine, U.S. Geological Survey, Woods Hole, MA 02543 TEL: (508) 457-2239 FTS: 837-4139

R. Gregory Lough, National Marine Fisheries Service, Woods Hole, MA 02543 TEL: (508) 548-5123 FTS: 840-1290 
Summary 1

Introduction 2

Regional setting of Georges Bank 4

Evolution of the sea floor environment 4

Eastern Georges Bank fishery and the sea floor environment 10

Juvenile cod 11

Sea scallops 11

Herring egg beds 13

Physical disturbance of the sea floor 15

Important questions for further study 19

Acknowledgements 21

Selected References 22

\section{ILLUSTRATIONS}

Figure 1. Map showing the location of the USGS-NMFS research area on eastern Georges Bank 3

2. Map showing water mass circulation patterns in the Georges BankGulf of Maine region 5

3. Map showing the topography of eastern Georges Bank 6

4. Map showing the sedimentary environment of eastern Georges Bank 8

5. Perspective view map showing sediment texture and mean bottom current speed of eastern Georges Bank 9

6. Map showing 7 sedimentary provinces of eastern Georges Bank 10

7. Five-year composite map showing the distribution and abundance of recently-settled juvenile cod 12

8. Six-year composite map showing the distribution and abundance of sea scallops 14

9. Five-year composite map showing the locations of herring spawning areas $\mathbf{1 6}$

10. Side scan sonographs showing gravel pavement disturbed by trawling and dredging on eastern Georges Bank 18

11. Photographs of the sea bed showing gravel pavement typical of trawled and untrawled areas of eastern Georges Bank 20 
The Influence of Geologic and Oceanographic Environmental Factors on the Abundance and Distribution of Fisheries Resources of the Northeastern United States Continental Shelf

Page C. Valentine and R. Gregory Lough

\section{Summary}

New digital data base maps are being compiled that show topography, sedimentary environment, and the distribution of fisheries species on eastern Georges Bank. These maps result from collaborative research undertaken by the U. S. Geological Survey and the National Marine Fisheries Service to examine how geologic, biologic, and oceanographic factors interact to structure the bank's environment. It is well known that sea floor habitat type is one of several important factors governing the abundance and distribution of fisheries species. However, the nature and geographic distribution of habitats on Georges Bank are not well documented. The results of this first attempt to map the sea floor environment in some detail are a potential basis for formulating new approaches to monitoring, managing, and studying the bank's resources and environmental processes. The maps illustrated here are simplified versions of large-scale $(1: 250,000)$ maps in press or in preparation.

The nature of the sea bed sediment varies widely on eastern Georges Bank, and it is a key element in the development of the biological community. Originally, this sediment was transported to the bank by glaciers; and since their retreat, it has been winnowed and redistributed by the action of rising sea level and by tidal, storm, and other currents. As a result, sediment texture on the bank ranges from very coarse gravel to muddy sand. In sandy, shallow areas ( 3 to 50 meters water depth), strong tidal currents have constructed large dunes and sand ridges. In deeper areas, bottom currents and sediment movement are slower, and the sea bed is smoother and finer-grained. A thin, coarse-grained pavement of gravel is a striking feature of the northern part of the bank; it includes areas of rough sea floor where many large boulders occur. Seven sedimentary provinces have developed on the eastern Georges Bank sea floor through the interaction of environmental factors such as bottom topography, availability and type of sediment, and the speed and direction of bottom currents.

The gravel pavement is a newly discovered feature of the sea bed that extends along the Northern Edge and Northeast Peak for $150 \mathrm{~km}$ and covers an area of more than $3000 \mathrm{~km}^{2}$. It forms as a lag deposit where strong currents winnow sand from coarse glacial sediment. The gravel, which is heavily trawled and dredged for groundfish and scallops, is interpreted to be an important habitat for the spawning and survival of fisheries species such as cod, scallops, and herring. 
The distribution patterns of juvenile cod on eastern Georges Bank suggest that the gravel habitat is the area where they are best able to avoid predators and to find food sources, and therefore, that the gravel may be essential for their survival and recruitment to the fishery.

Sea scallops on eastern Georges Bank are most abundant on gravel or gravelly sand habitat and are almost absent from sandy areas. This distribution appears to be related to the inability of juvenile scallops to colonize areas of the bank where strong currents and shifting sand result in their burial and in the clogging of their feeding apparatus.

The location of herring spawning grounds indicates that the coincidence of gravel pavement and strong tidal currents produces a unique environment where the eggs can attach to a firm substrate and hatch in clean, oxygenated water. This area is limited to the shallow, western part of the gravel habitat on the bank's Northern Edge.

Physical disturbance of the sea bed is caused by strong, erosive currents (tidal and storm), which construct and move sand features across the bottom. Moving sand alternately buries and exposes other sea floor habitats, and thereby alters the structure and composition of the biological community. In addition to this natural reworking of the surficial sediments, much of eastern Georges Bank is trawled and dredged for groundfish and scallops, which disturbs and turns over the sea bed. In untrawled, gravel-dominated areas of the Northern Edge and Northeast Peak, there exists a biologically diverse community dominated by abundant attached organisms. The presence of these organisms certainly increases the fine-scale, biological roughness of the sea bottom, and, by modifying the sea bed, they may play an important role in the fisheries habitat. By contrast, in heavily trawled areas of the gravel habitat, this community is poorly represented, and the bottom is relatively smoother.

\section{Introduction}

The purpose of this report is to present results of recent environmental studies of eastern Georges Bank (Fig. 1) and to preview maps that show correlations between sea floor environments and the abundance and distribution of sea scallops and juvenile cod and the location of herring spawning grounds.

The marine environments of eastern Georges Bank are structured by the interaction of many factors. 1. Water depth ranges from 3 to $150 \mathrm{~m}$ and affects the penetration of sunlight and the strength of waves and currents on the seabed. 2 . Topography varies from steep sand ridges 20 to $30 \mathrm{~m}$ in height found in shallow water (which channel the flow of bottom currents) to the relatively gentle regional slope of the deeper bank surface. 3. Sediment types and associated prey organisms provide substrates that affect the growth of fisheries species. 4. The flow of currents moves sediment, constructs dunes and ridges, mixes bottom and surface waters, and transports nutrients and small plants and animals. 5. Oceanographic frontal systems form environmental gradients (sharp changes in temperature, salinity, and nutrient concentration) between the Georges Bank water and the distinctive waters of adjacent regions (Gulf of Maine, Scotian Shelf, Atlantic Ocean). The diverse biological 


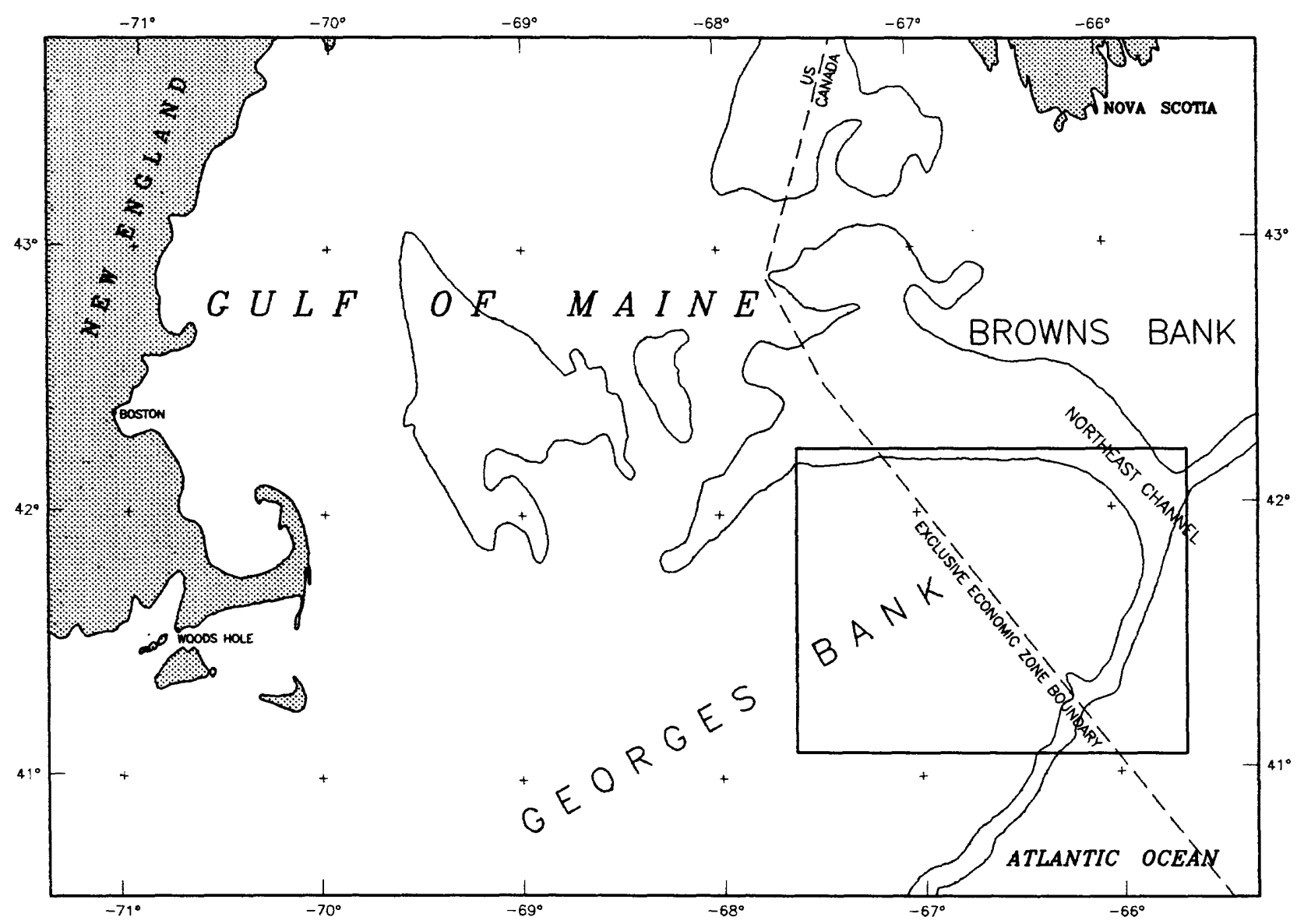

Figure 1. Map showing the location of the U.S. Geological Survey-National Marine Fisheries Service research area on eastern Georges Bank. Scale 1:3,230,000 ( 1 inch $=51$ miles).

communities of the bank and the abundance and distribution of fishery species appear to be related in a complex way to environmental factors, to biological interactions, and to the impact of human activities, including the removal of fish stocks, and the physical disturbance of the sea bed.

Many of the organisms that are important to the Georges Bank fishery exhibit a close relationship with the sea floor environment during a part of their life cycle. The habitat may serve as a spawning ground, a nursery area for juveniles, or a suitable environment for growth of prey species, among other functions. Cod, haddock, scallops, lobsters, and many other species dwell on the sea floor for most of their lives, but spend their early months of growth and development (egg, larval, and juvenile stages) in the water column near the sea surface. By contrast, herring spend most of their lives in the water column above the bottom, but their eggs require attachment to a firm substrate for hatching.

During the past 10 years, many Georges Bank fishery populations such as cod, haddock, herring, and scallops have declined while others such as skate and dogfish have expanded rapidly (National Oceanic and Atmospheric Administration, 1991). Decades of research on the bank by geologists, oceanographers, and fisheries biologists has shown that it is difficult to document direct interactions between environmental factors and fisheries species. A major problem is the lack of maps of the sea floor 
environment at scales that will reveal these relationships. A comprehensive knowledge of the regional environmental framework is required to provide a basis for answering questions regarding the health of a fishery, the effects of ocean dumping and pollutant dispersal, or the impact of offshore mining and energy production.

Recently, scientists of the USGS and the NMFS have undertaken a multidisciplinary effort to map eastern Georges Bank in order to identify relationships between the physical and biological aspects of the environment in more detail than previously has been attempted. New digital data base maps have been compiled (scale = 1:250,000; 1 inch = 4 miles) that show the topography, sedimentary environment, and distribution of fisheries species (Valentine and others, 1991a, 1991b). Maps showing the relationships of juvenile cod, scallops, and herring egg beds to the sedimentary environment are shown in condensed form here. These maps are compiled from both published reports and new data from our most recent studies. Methods of data collection include sidescan sonar and seismic reflection surveys, observations and sampling from submersibles, bottom sampling for sediment and herring egg beds, and trawling for juvenile cod and scallops.

\section{Regional Setting of Georges Bank}

Georges Bank is a shallow (3-150 m water depth), elongate extension of the northeastern U. S. Atlantic continental shelf east of New England (Fig. 2). It covers an area of some $40,000 \mathrm{~km}^{2}$ and is bounded on the north by the deeper waters of the Gulf of Maine and on the south by the Atlantic Ocean. The bank is eroding, and no sediment is transported to it from the continent or from adjacent shelf regions. Glacial debris covers the bank, and sand is winnowed from it and transported into deep water by strong tidal and storm currents; the gravel remains. Tidal currents flow dominantly northwest and southeast. In shallow areas, tidal currents mix bottom and surface waters and combine with weaker current systems to form a broad current gyre that circulates clockwise around the bank (Brooks, 1985; Butman and others, 1987; Loder and Greenberg, 1986). Oceanographic frontal systems separate the generally well-mixed bank water from stratified water of the Gulf of Maine and the Atlantic Ocean; these water masses (including occasional warm-core rings of Gulf Stream water) differ in temperature, salinity, nutrient concentration, and in the small planktonic plants and animals that inhabit them.

\section{Evolution of the Sea Floor Environment}

Sea floor environments on eastern Georges Bank range from highly energetic on the shallow bank crest, as represented by rugged sand ridges $20-30 \mathrm{~m}$ high and an extensive gravel pavement, to a relatively smooth sea bed toward the southern flank of the bank, where the bank surface is finer-grained sediment (Fig. 3; Valentine and others, 1991a). By the end of the last great ice advance approximately 18,000 years ago, an ice sheet filled the Gulf of Maine, exterided onto the northern and eastern edges of the bank, and flowed seaward through the Northeast Channel (Hughes and others, 1985). At that time, sea level was approximately $100 \mathrm{~m}$ lower than it is in the region at present. Georges Bank was covered by moraines of rock debris deposited from the ice and by outwash deposits transported by water flowing southward from the glacier (Schlee 1973; 

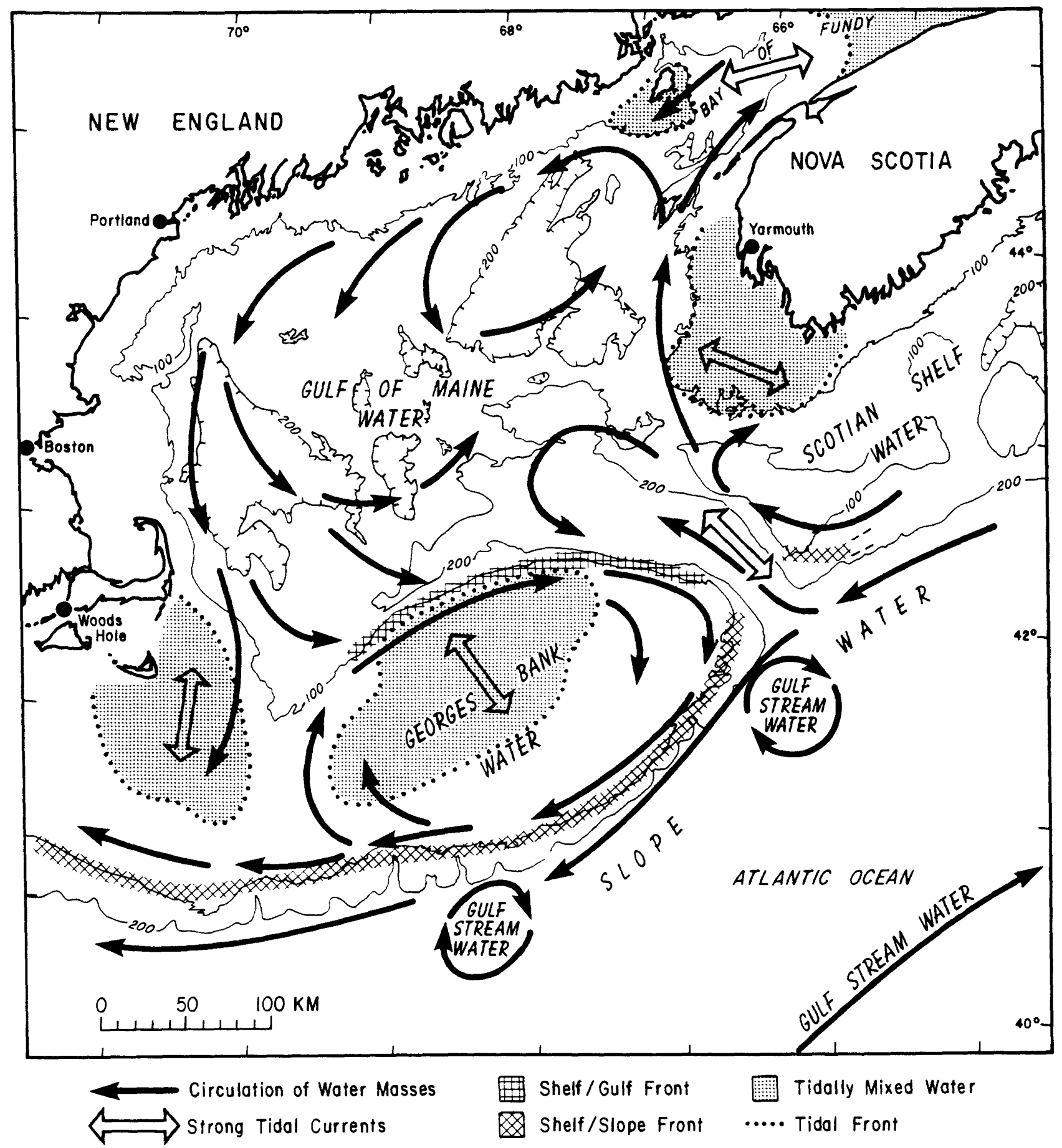

Figure 2. Map showing water mass circulation patterns in the Georges Bank-Gulf of Maine region. Water masses exhibit distinctive physical properties (temperature, salinity, stratification, mixing, nutrient concentration). Mixing of bottom and surface waters in shallow areas by strong tidal currents recycles nutrients which leads to high biological productivity. Depths in meters. Scale 1:3,600,000 (1 inch $=57$ miles). (after: Brooks, 1985; Butman and others, 1987; Loder and Greenberg, 1986)

Schlee and Pratt, 1970; Emery, 1987). The coarsest sediment was laid down beneath the glacier and along its seaward margin on the northern and eastern parts of the bank, where today the sea floor is armored by a gravel pavement. 


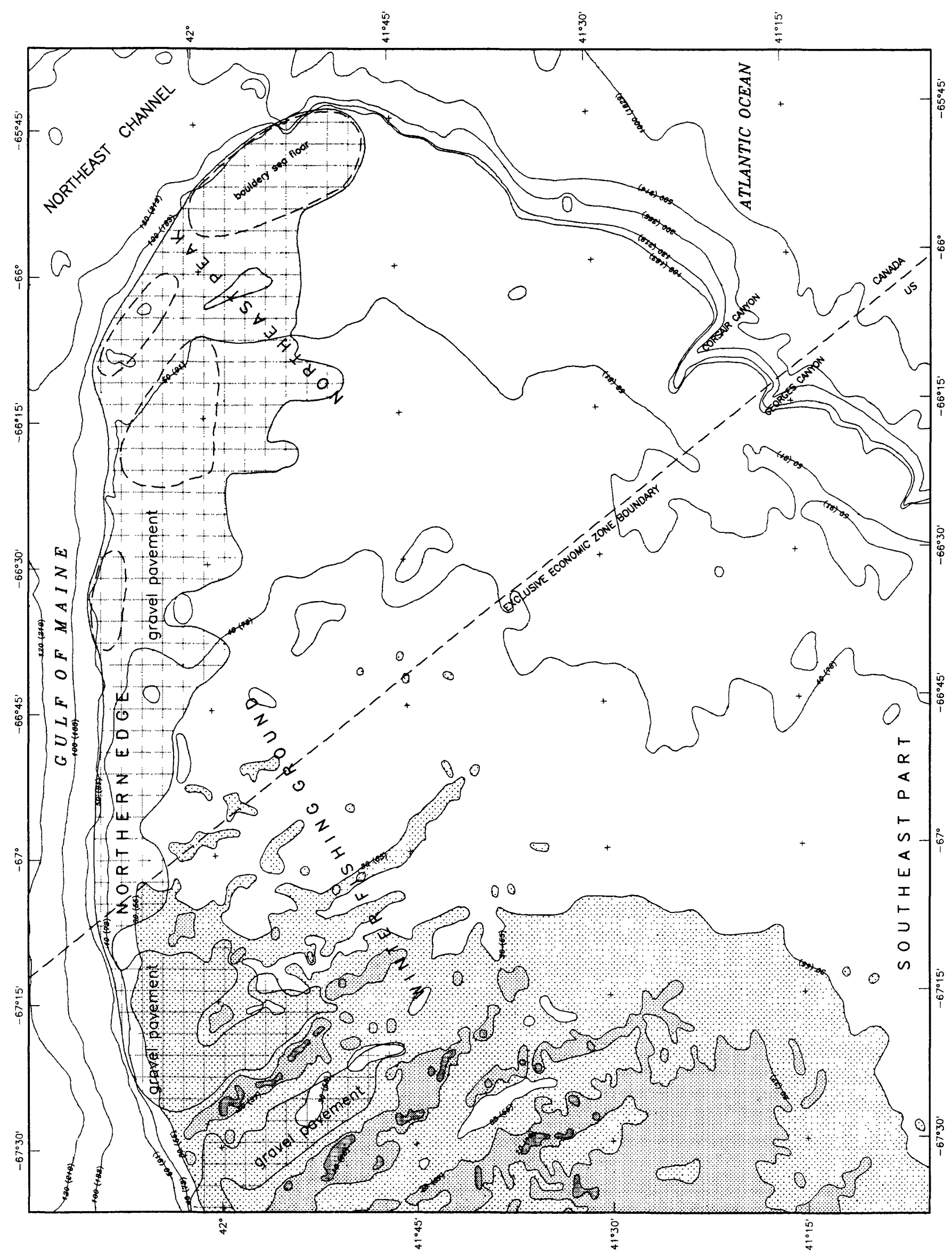


Glacial retreat and rising sea level marked the start of an erosional episode that continues today and is recorded in the modern sediment patterns observed on the bank (Figs. 4, 5; Valentine, 1991; Valentine and others, 1991b). By using the modern sea floor textures and features (and the environmental processes that formed them on this shallow bank) as a model, we envision the evolution of the sea floor as follows. Glaciers retreated from the northern and eastern part of the bank, leaving hummocky mounds of rock rubble composed of sediment that ranged in size from mud to large boulders. The more southerly part of the bank was covered by sand and fine gravel carried by water flowing from the melting glacier. The sea flooded the bank and eroded glacial sediment and landforms, thus reworking and smoothing the bank surface. Sand and mud were winnowed and transported off the bank onto the southern bank margin and northward into the Gulf of Maine. High sand ridges, similar to those now present on the bank crest, grew in shallow water in response to the flow of strong tidal currents.

The advance of the sea, accompanied by increasing water depth and continued erosion, caused sea floor sediment textures to change. Sand ridges that had grown in shallow water were eroded; younger ridges formed in newly submerged areas. A thin gravel pavement (similar to gravel lag deposits that form in deserts as sand is removed by wind) evolved in areas of the coarsest glacial deposits. Glacial sediment on the southern part of the bank was reworked into a broad sheet of gravelly sand and low sand dunes and ripples. The shallow crest of the bank, the last part to be submerged, is now covered by sand that is being transported across the sea bed by tidal and storm currents and built into high sand ridges and dunes. In low places between sand ridges, gravel deposits are visible. Erosion by storm and tidal currents continues, and the bank surface is becoming coarser as sand is removed to deep water. Areas of gravel pavement and gravelly sand are expanding westward along the northern edge of the bank into areas now dominated by sand sheets and sand ridges.

Seven sedimentary provinces (based on sediment texture and bedforms, current speed, and sea floor morphology) have formed on eastern Georges Bank as a result of the processes described above (Fig. 6). The texture of each province is closely related to bank topography and water depth, and to the strength of tidal bottom currents and the availability of movable sediment. On the Northern Edge and Northeast Peak (province 1), the sea bed is more than 70 weight percent gravel which is packed tightly into a thin pavement overlying a mixture of sand and gravel; boulders are common in several areas (outlined by dashes in Figures 3-8). The gravel pavement extends for $150 \mathrm{~km}$ along the Northern Edge and Northeast Peak and covers an area of more than $3000 \mathrm{~km}^{2}$. It is a major feature of the eastern Georges Bank sea floor, and its nature and extent were determined during the present research. On the northern slope and in Northeast Channel (province 2), sediment texture is highly variable and includes gravel, but it is dominantly gravelly sand; it is a transitional region between the coarser gravel pavement and the finer sediment of the Gulf of Maine and the Atlantic slope. The texture of the north central shelf (province 3 ) is also gravelly sand, but rippled sand and sand dunes are present. The shallow bank crest and the central and southwest region of the shelf (province 4) are chiefly sand formed into large dunes and ridges. Between the sand

Figure 3. Map showing topography of eastern Georges Bank (shallow areas are stippled) and the lateral extent of the environmentally important gravel pavement (grid pattern). Dashed lines enclose areas of bouldery sea floor that are infrequently trawled by fishermen. Depths in fathoms (meters). Scale 1:745,000 (1 inch $=12$ miles). 


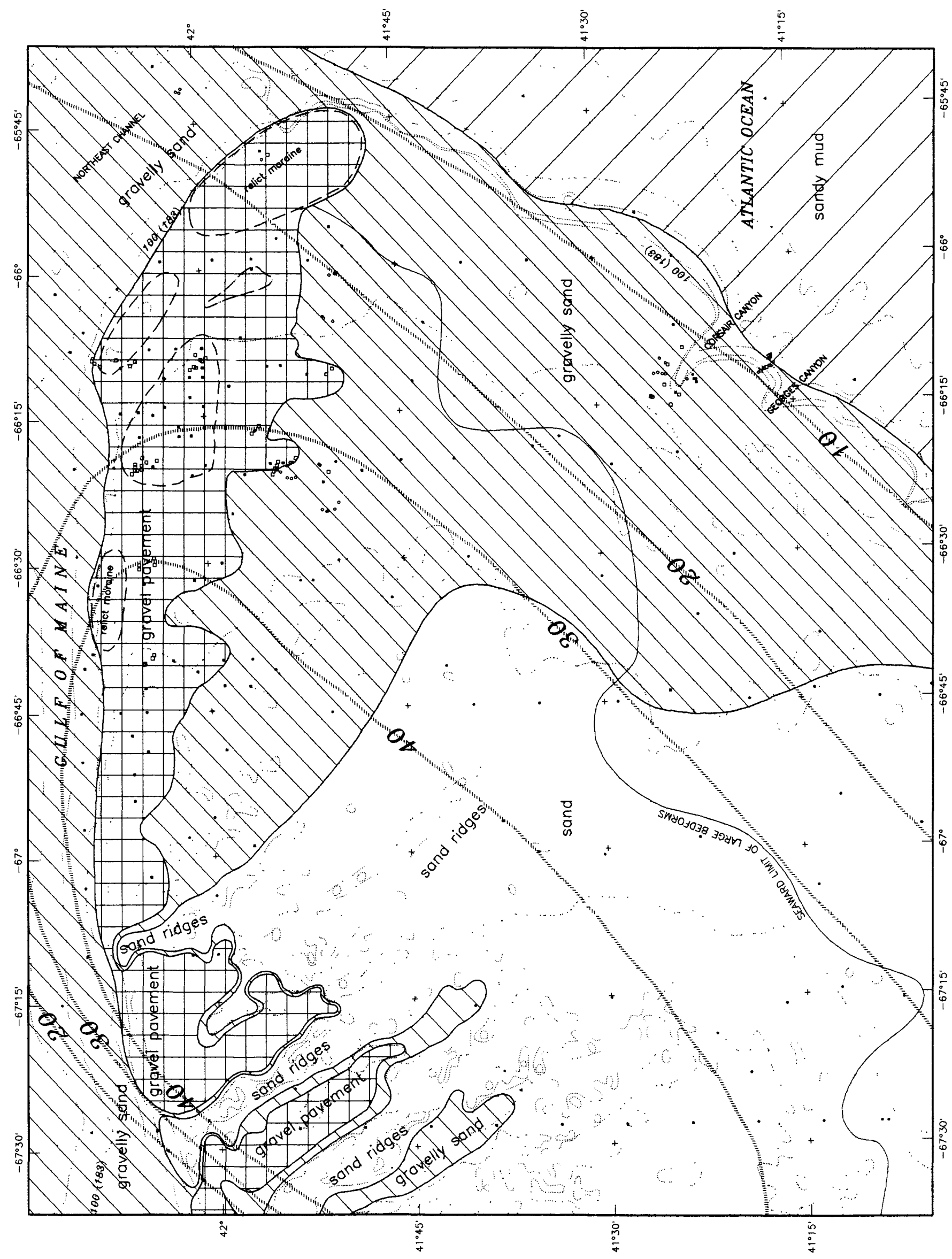




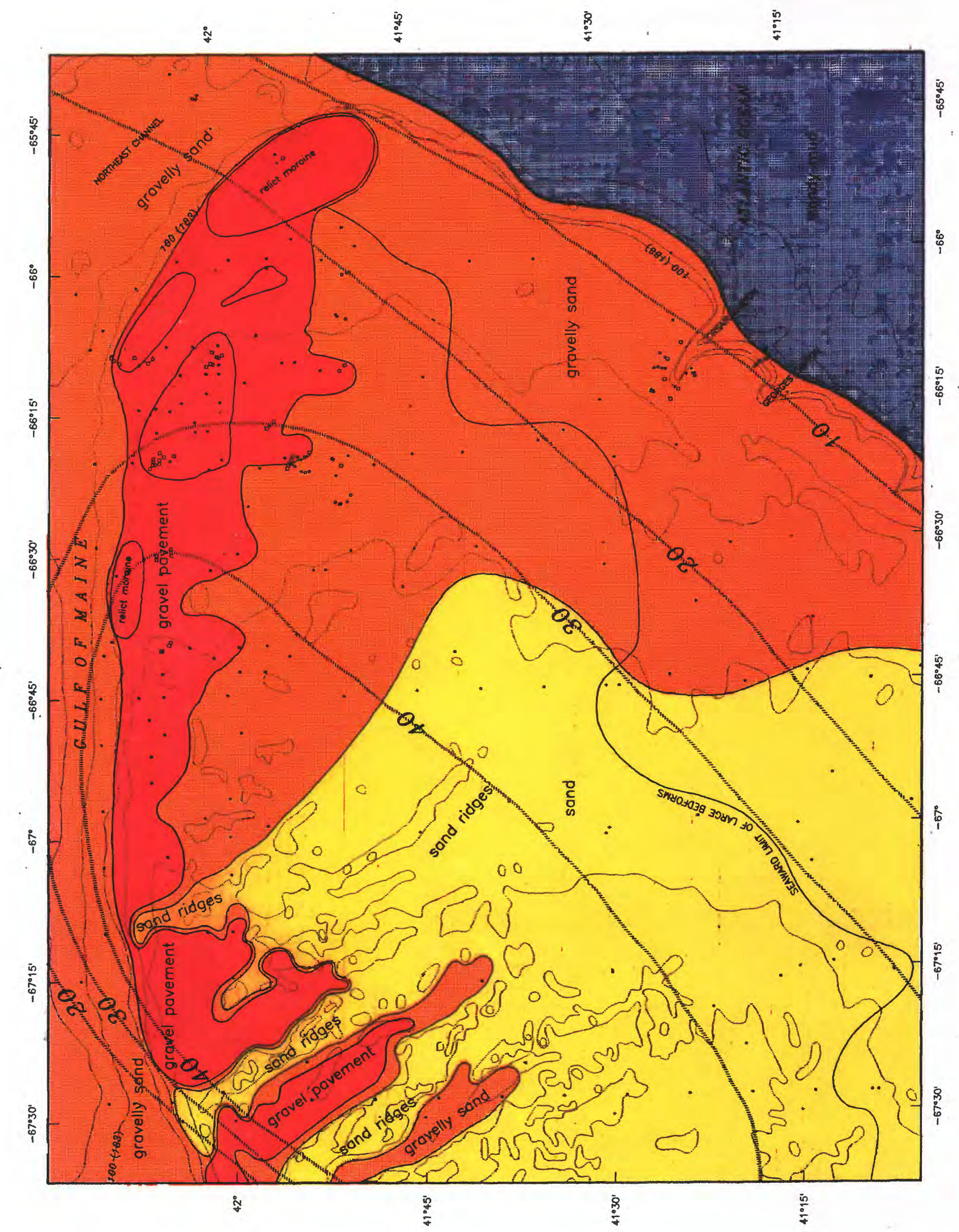




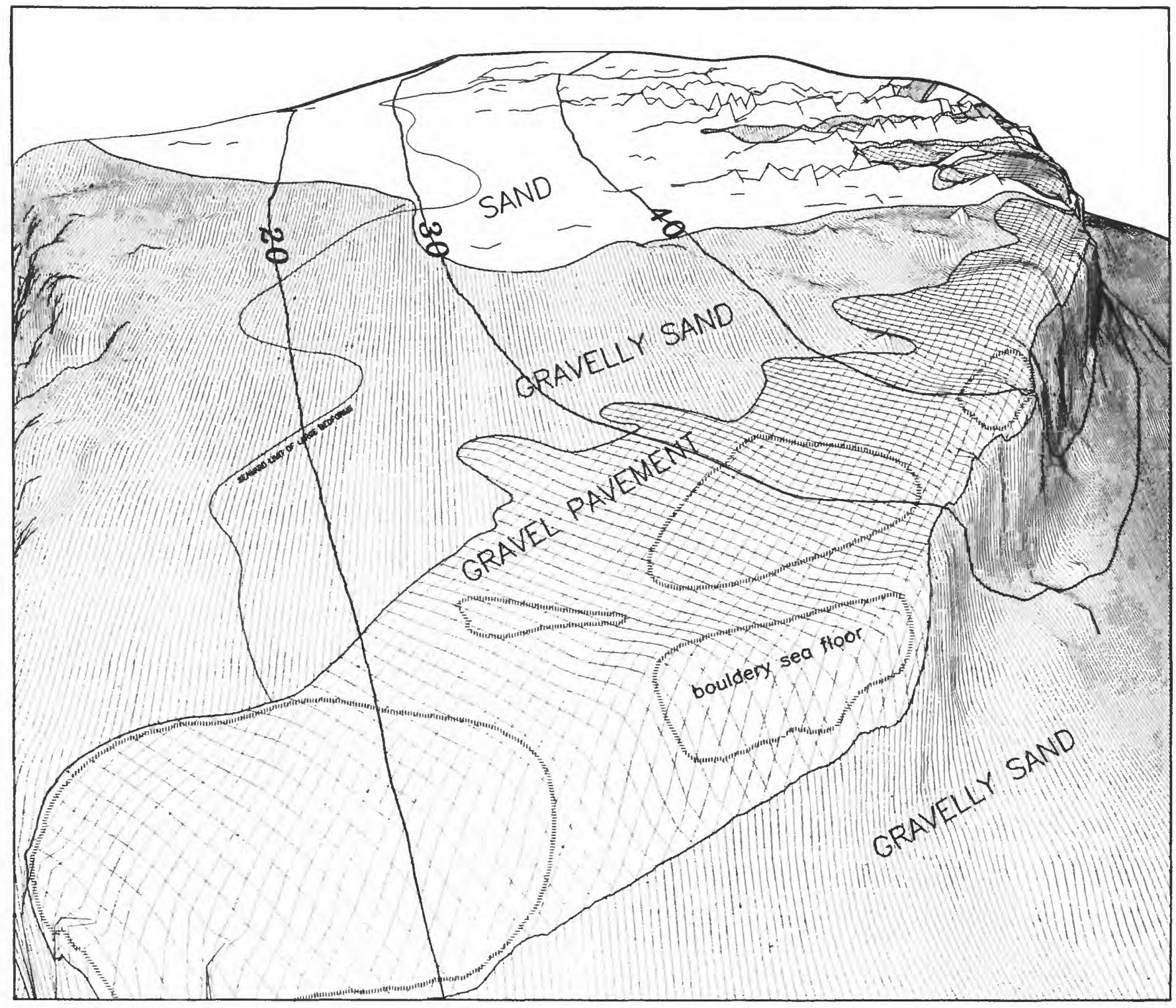

Figure 5. Perspective view map looking southwest from Northeast Channel (Fig. 4) showing sea floor texture and mean tidal bottom current speed $(\mathrm{cm} / \mathrm{s})$ on eastern Georges Bank; eyepoint is $880 \mathrm{ft}(268 \mathrm{~m})$ above sea level and distance to the horizon is $127 \mathrm{mi}(205 \mathrm{~km})$; vertical exaggeration is 100 . Strongest currents are on the shallow, Northern Edge and extend into deeper water on the northern flank. Map shows the transition from gravelly, relatively smooth topography in the east (foreground) to sandy, very rough topography (sand ridges) in the west. Gravel pavement (includes areas where boulders are common) forms on the Northern Edge as sand ridges are eroded away and results in a gradual coarsening of the bank surface to westward.

Figure 4. Map showing the sedimentary environment of eastern Georges Bank, including sea floor morphology, texture, and mean tidal bottom current speed in $\mathrm{cm} / \mathrm{s}(50 \mathrm{~cm} / \mathrm{s}=1 \mathrm{~nm} / \mathrm{hr})$. Strongest tidal currents flow parallel to sand ridges. Bottom sample stations shown; sidescan sonar and seismic surveys not shown. Relict moraines are interpreted to be bouldery material deposited by former glaciers; these areas are less frequently trawled than other parts of the bank. Depths in fathoms (meters). Scale 1:745,000 (1 inch = 12 miles) 


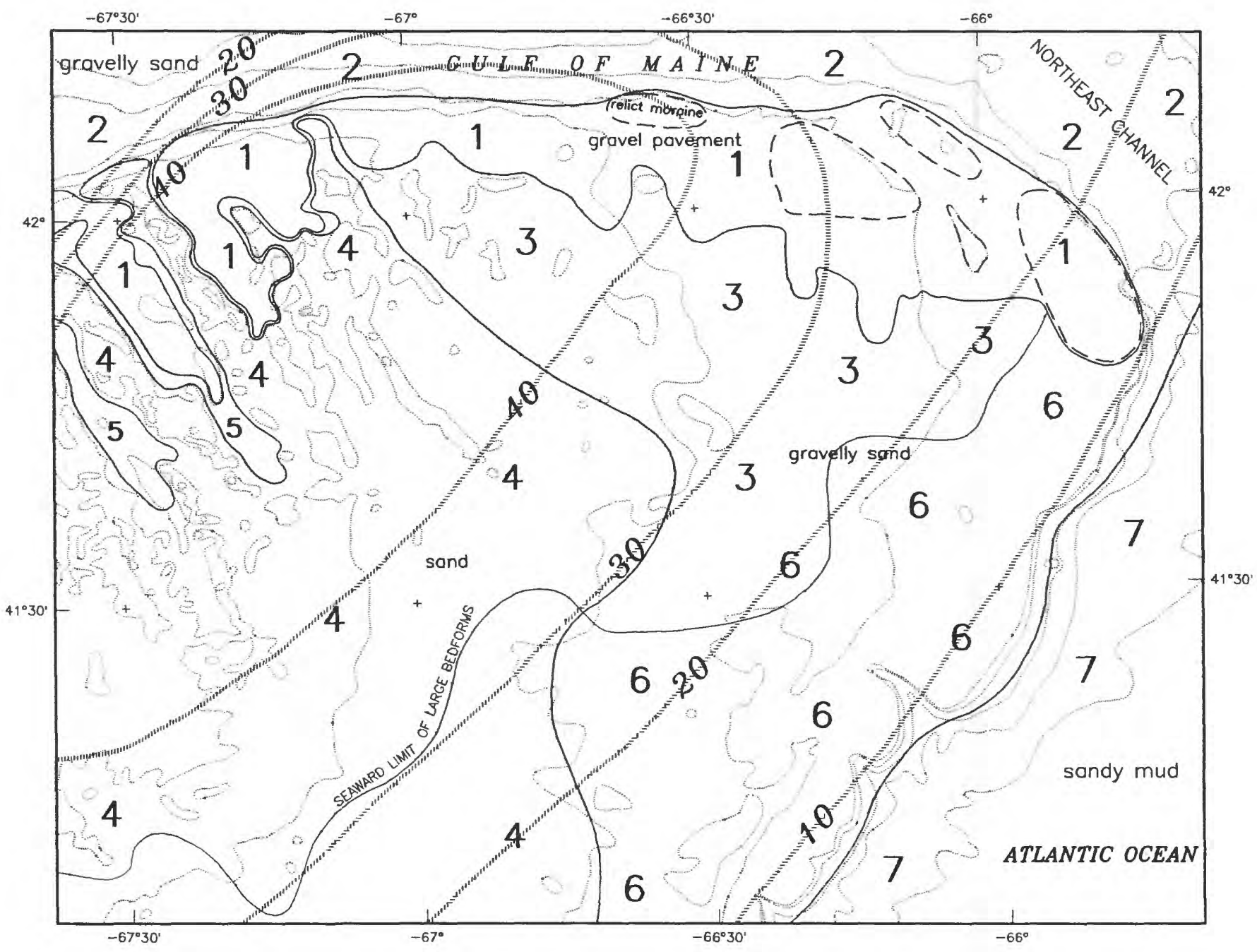

Figure 6. Map showing 7 sedimentary provinces of eastern Georges Bank based on criteria of sea floor morphology, texture, sediment movement and bedforms, and mean tidal bottom current speed (cm/s). Relict moraines (bouldery sea floor) are enclosed by dashed lines. See text for descriptions of provinces. Scale $1: 1,000,000$ ( 1 inch $=16$ miles).

ridges on the bank crest, gravelly sand lies in elongate patches (province 5). On the southeast region of the shelf (province 6), the sea bed is gravelly sand but sand dunes are not common. Finally, the southeastern slope (province 7) is covered by muddy sand. Though at present these sedimentary provinces are only broadly defined on eastern Georges Bank, we observe direct and obvious correlations between their presence and the abundance and distribution of important fisheries species.

\section{Eastern Georges Bank Fishery and the Sea Floor Environment}

The Georges Bank fishery is in a depressed state, and many species are overexpoited (NOAA, 1991). Our mapping on eastern Georges Bank has revealed relationships between the distribution and abundance of several fisheries species (cod, sea scallops, herring) and particular sea bed environments. Based on these results, it is probable that efforts to improve and maintain the health of the fishery will benefit from a detailed knowledge of the characteristics and areal distribution of sea floor habitats and of how biological communities depend on them. 
Georges Bank codfish spawn near the sea floor in February and March. The fertilized eggs rise in the water column and drift around the bank in the clockwise current gyre for several weeks before hatching into larvae. Two to three months after hatching, the larvae transform into juvenile fish which are widely distributed in the waters over eastern Georges Bank. By July, the juvenile fish have reached a length of 4 to $6 \mathrm{~cm}$ at which time they descend to the sea floor where they spend the rest of their lives. Upon settlement onto the sea bed, the juveniles are widely dispersed over the bank and are present on bottom types ranging from sand to gravelly sand to gravel pavement. However, in late July and August, the juveniles are present predominantly on the gravel pavement habitat on the northeastern part of the bank and are absent from the sandy bottoms (Fig. 7). This phenomenon is confirmed by data collected during 5 years of observations (1984-87, 1989). The coloration of the juveniles mimics the appearance of the gravel, possibly making them less vulnerable to predation there than on the more uniform, light-colored sand bottom that is typical of large areas of the bank.

These observations suggest that the gravel habitat favors the survival of the juveniles through predator avoidance, possibly coupled with increased food availability associated with the frontal system (Fig. 2) present along the northern margin of the bank (Lough and others, 1989). Most of the gravel pavement is heavily trawled and dredged for groundfish and scallops, but some areas are so rough with boulders that they are avoided by fishermen, and there a rich community characterized by abundant attached organisms is present on the sea bed. The attached members of this community are much less common on trawled and dredged gravel bottom. Juvenile cod are present on both trawled and untrawled gravel. The gravel (trawled and untrawled) is interpreted to be an important habitat for the survival of juvenile cod and may be essential for their successful recruitment to the fishery. By day the cod remain on the bottom, but at night they rise several meters into the water column and drift in the tidal current while feeding. During late summer, as the juveniles continue to grow, they are carried to the east and southeast in the residual bottom current gyre, and by fall they are more widely dispersed and are no longer confined to the gravel pavement habitat.

\section{Sea Scallops}

For most of their lives, sea scallops inhabit the sea bed and feed by filtering small organisms and particles from the bottom water. During spawning in autumn (AugustSeptember) and in spring (April-May), eggs are released into the water column where they soon hatch, and larval stages drift around the bank in the surface water (G. Robert, Department of Fisheries and Oceans, Canada, personal communication, 1991). Three to four weeks after hatching, larval scallops settle to the bottom. Scallops at this stage are less than 1 centimeter in diameter (G. Thouzeau, DFO, personal communication, 1991). For a short period of time (approximately one month), they are able to test the bottom for suitable substrate before they settle and form a thread-like attachment to it (Culliney, 1974). Most juveniles attach to sediment particles (sand grains, gravel, shells) or to attached organisms such as bryozoa or hydrozoa, but as scallops mature, attachment becomes less common (Caddy, 1972). 


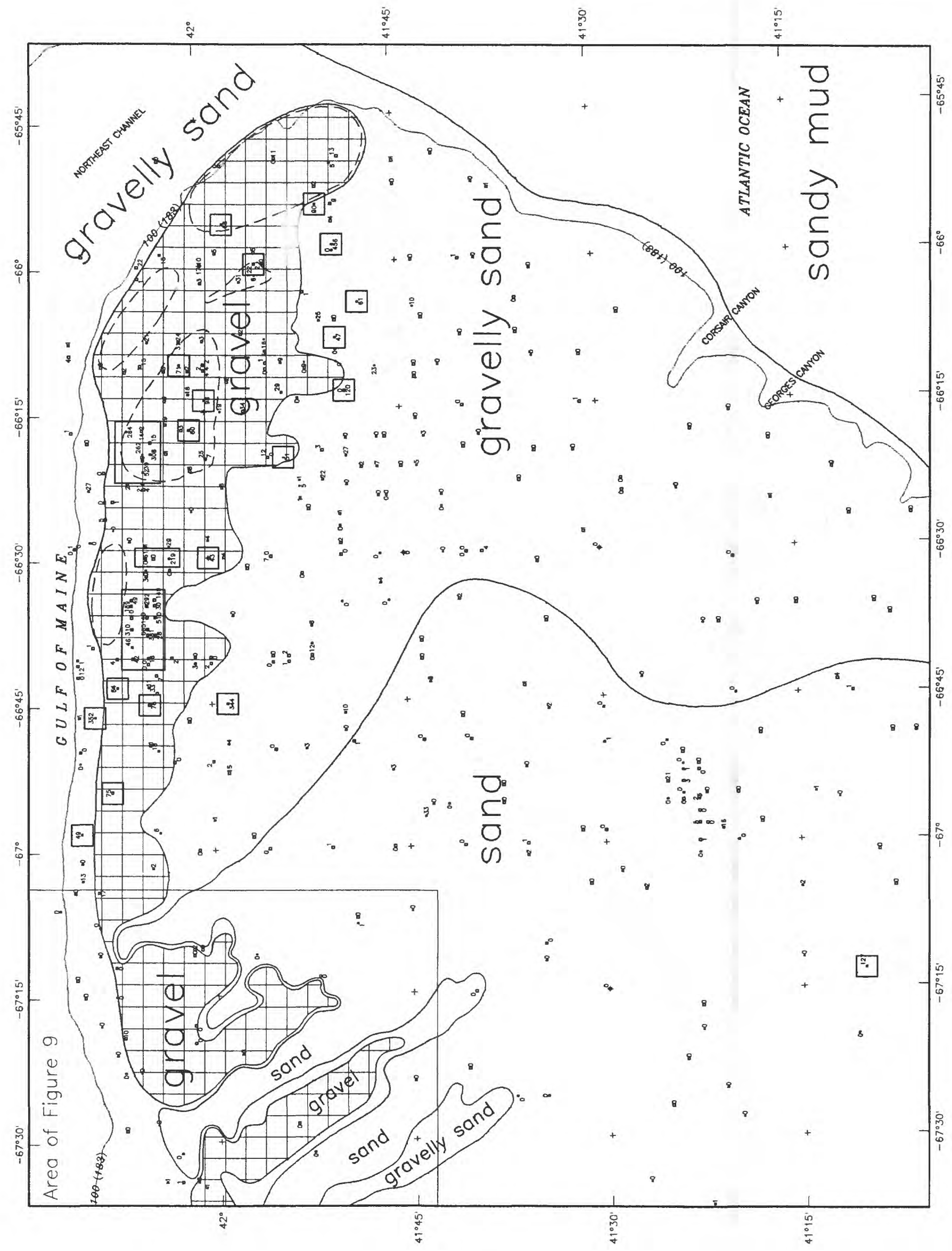


Scallop surveys conducted on eastern Georges Bank in late summer for 6 seasons in 1977, 1983, 1986-88, and 1990 show a strong relationship between the numbers of scallops present and the type of sea floor they habitat (Fig. 8). Scallops were most abundant on the gravel pavement and in the gravelly sand on the north central and southeastern parts of the bank where the sea bed is coarse-grained, and the movement of sand and the formation of sand dunes is relatively minor. By contrast, scallops were present in very low numbers or absent on sandy bottom where sand movement and the formation of sand features occurs. This region is located on the shallow bank crest and in the central and southwest region of eastern Georges Bank where sand is being transported toward the bank margins by strong bottom currents. Mean tidal bottom currents here range from 20 to greater than $40 \mathrm{~cm} / \mathrm{s}$ (Figs. 4, 5).

Sea scallop larvae are widely distributed over eastern Georges Bank while they are in the water column (Tremblay and Sinclair, in press), and, therefore, they will likely settle onto all the habitats offered by the sea floor. However, comparison of distributions of scallops and sea floor habitats shows that scallops survive best on gravel and gravelly sand where they can find firm attachment surfaces (Thouzeau and others, 1991a; this study). It is probable that juvenile scallops do not survive well in areas where the formation and movement of sand features are a major environmental factor. Moving sediment may clog the scallops' food filtering apparatus and thus prevent feeding. Moreover, the small juvenile scallops are weak swimmers, and they are most vulnerable to burial by moving sand during the period soon after settlement when they are attached to the bottom (Larsen and Lee, 1978; Thouzeau and others, 1991a). Thus, it may not be possible for scallops to colonize a large area of eastern Georges Bank where the sea bed is mobile sand. By contrast, adult scallops are strong swimmers over short distances and may be able to avoid burial if, on occasion, they encounter moving sand in an otherwise gravelly area.

\section{Herring Egg Beds}

Georges Bank herring lay their eggs on the sea floor in the autumn, and peak spawning occurs in late September and early October. Herring eggs hatch within 5-10 days and the larvae ascend into the overlying water and drift in the Georges Bank current gyre where they become juvenile fish within 5 to 7 months (Lough and others, 1982). Unlike cod, after herring transform into juvenile fish they do not inhabit the sea bottom but remain in the waters over the bank.

Herring eggs require a firm surface for attachment, and the preferred bottom type in the North Atlantic is gravel associated with strong bottom currents (eggs are attached to algal fronds in the Gulf of St. Lawrence and off the coast of Nova Scotia; McKenzie, 1964; Tiboo and others, 1963). Egg beds on Georges Bank have been observed from submersibles to occur on gravel and to form mats several centimeters in thickness that extend for hundreds of meters over the sea bed (Caddy and Iles, 1973; Drapeau, 1973).

\footnotetext{
Figure 7. Five-year composite map showing the distribution and abundance of recently-settled juvenile cod in relation to the sedimentary environment during the seasonal period July 21-August 20 (1984-87, 1989). Highest concentrations were on the gravel pavement (pattern), and cod were rare or absent on sandy bottom; boxes enclose samples of 40 or more juvenile cod (collected with standard research trawl). Dashed lines enclose areas of bouldery sea floor. Depths in fathoms (meters). Scale 1:745,000 (1 inch $=12$ miles).
} 


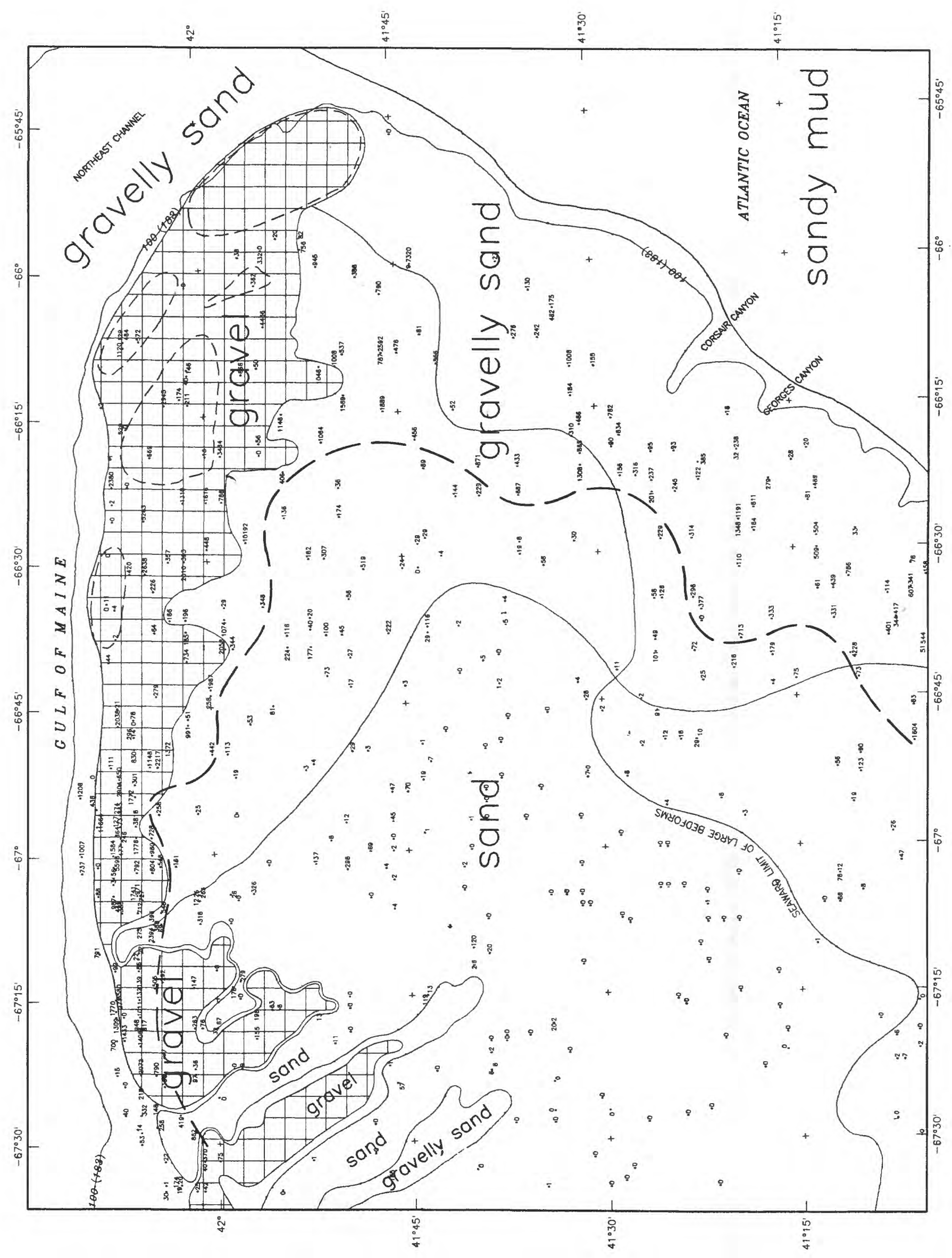


The very large gravel pavement on the northern edge of the bank would appear to provide ample favorable habitat for the attachment of eggs. However, surveys conducted during 5 spawning seasons $(1964-66,1969,1970)$ found the egg beds to be located in a relatively small region on the western end of the gravel (Anthony and others, 1970; Noskov and Zinkevich, 1967; Pankratov and Sigajev, 1973). These historic spawing sites are in elongated areas of gravel pavement (at water depths of 40 to $50 \mathrm{~m}$ ) bounded by gravelly sand and large sand ridges 10 to $20 \mathrm{~m}$ in height (Fig. 9). Apparently only a relatively small part of the gravel pavement on eastern Georges Bank is suitable for herring spawning grounds, as the herring restricted their egg laying to the shallowest part of the gravel which lies between sand ridges and experiences the strongest tidal currents. At present, the gravel is extensively trawled and dredged for groundfish and scallops.

The eastern Georges Bank herring population was abundant in the 1960's but collapsed in the early 1970's (NOAA, 1991). The 1970 survey found only small patches of eggs, in contrast to the large patches found in 1964-66. We have just completed the most comprehensive survey since 1970 of the historic herring spawning grounds shown in Figure 9. During the period October 7-12, 1991, no herring eggs were found in 136 dredge samples of the area, and no herring larvae were found in samples of the water column; an indication that the eastern Georges Bank population has not recovered.

\section{Physical Disturbance of the Sea Floor}

It is clear that the character of sea floor habitats on eastern Georges Bank is directly related to the texture of the sediment present and to the strength of bottom currents. The sea floor environment is apt to change most rapidly in shallow, sandy areas where strong currents move sand to construct bedforms that range from a few centimeters up to many meters in height. For example, mobile sand can cover a gravel habitat, thus altering the makeup of the biological community living there. Strong currents have less affect on the sea bed in areas of the gravel pavement where little surficial sand is present; there, small buildups of sand can exist only for a relatively short time during their transit into deeper water on the bank margins. This physical alteration of sea floor shape and texture results from the ebb and flood of tidal currents across the bank and is considered the environmental norm. Occasionally, violent storms generate short-lived, very strong currents that are capable of moving large amounts of sand and of disturbing the sea bed at greater water depths than can tidal currents. Storms occur chiefly in the fall and winter months and potentially can affect biological organisms adversely by transporting larvae and juveniles into an unsuitable habitat (for example, off the bank) or by smothering bottom-dwelling species with sand.

In addition to physical alteration of the sea floor by natural causes, disturbance of the habitat also occurs as a result of fishing with bottom trawls and dredges. Fishing for

Figure 8. Six-year composite map showing abundance and distribution of sea scallops in relation to the sedimentary environment $(1977,1983,1986-88,1990)$. Scallops were most abundant (300 or more collected with a standard research dredge) on gravel and gravelly sand habitat outside the heavy dashed line to a depth of approximately $50 \mathrm{fm}(91 \mathrm{~m})$. Scallops were rare or absent where movement of sand is a dominant environmental factor (mean tidal bottom current speed 20 to greater than $40 \mathrm{~cm} / \mathrm{s} ;$ Fig. 4). Light dashed lines enclose areas of bouldery sea floor. Depths in fathoms (meters). Scale 1:745,000 ( 1 inch $=12$ miles). 


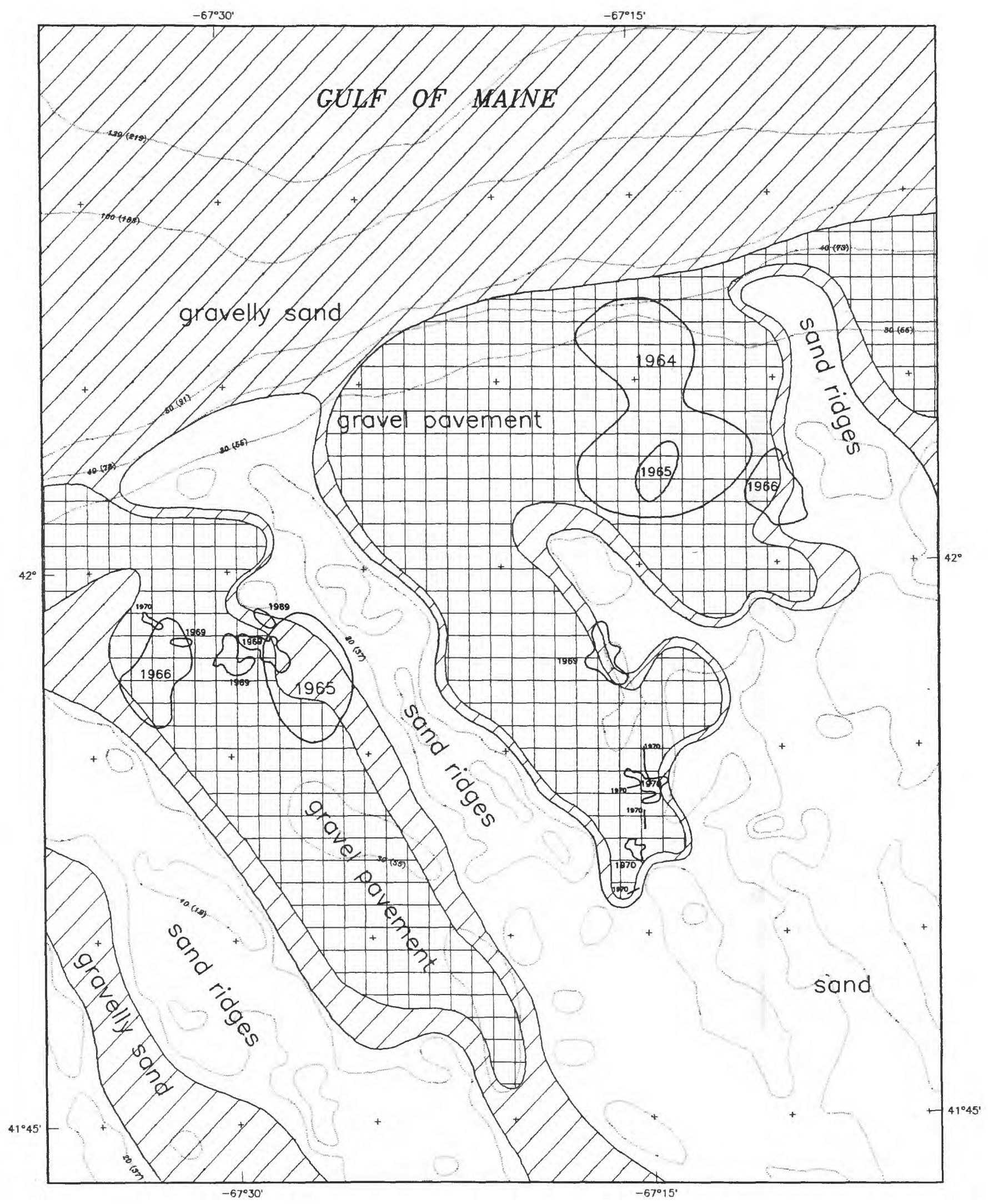


groundfish or scallops occurs over much of eastern Georges Bank, although some areas are more heavily fished than others, and some are favored above others for certain species. The two kinds of gear that are in common use are groundfish trawls and scallop dredges. Groundfish trawls are pulled over the bottom, with the mouth of the net riding on rollers just above the sea bed. The net is kept open by two large, heavy, flat boards ("doors") that are positioned vertically on either side of the mouth and that gouge the sea bed as they move forward. Scallop dredges are chain bags mounted on a metal frame; the bottom edge of the mouth penetrates the sea bed as the dredge is pulled along the bottom.

Observations using side scan sonar and submersibles show that the fishing gear cuts into and turns over the sea floor (Fig. 10). Disturbed sea bed is most evident on the gravel pavement where long, low mounds of gravel have been formed by trawling and dredging. Bottom currents, though strong, are too weak to move the gravel, and there is too little sand moving to bury the scars. In some areas the sea bed appears to be covered by trawl and dredge marks, based on interpretation of side scan sonographs. By contrast, physical disturbance of sandy areas is less evident because trawl and dredge features are obliterated by moving sand.

In trawled areas, the degree of abrasion of organisms attached to gravel particles appears to be related to fishing intensity. Several areas of the gravel habitat that are avoided by fishermen due to the presence of large glacial boulders that damage gear (Figs. 3,4 ) provide evidence that fishing activity has altered dramatically the structure of the bottom-dwelling community. Observations from submersibles showed that the gravel is covered with calcareous worm tubes and other attached organisms in areas where trawling is infrequent, and that the same organisms are much less common on gravel in trawled areas (Fig. 11). Moreover, the attached community increases the biological roughness of the sea floor, while the trawled gravel is smoother. A recent study has shown that the diversity and density of bottom-dwelling species is many times greater in gravel areas that support dense aggregations of worm tubes than in adjacent gravel areas where the worm tubes are absent (Thouzeau and others, 1991b). It is possible that prior to the onset of modern trawling and dredging on the northern margin of the bank, the entire gravel pavement supported a bottom community in the abundance that exists now only in untrawled areas.

It is not known whether physical disturbance of the sea bed by fishing has a positive or negative effect on the fishery itself. Juvenile cod have been observed to inhabit both trawled and untrawled gravel. However, we do know that fishing activity causes mixing of the upper part of the sea bed, and that it impedes the colonization of gravel bottom by attached organisms, thus reducing local roughness and reducing overall biological diversity and abundance. The gravel habitat of the Northern Edge and Northeast Peak may be an ideal region for comparative studies of the effect of trawling and dredging on fisheries species, on associated prey and predators, on sea floor

Figure 9. Five-year composite map showing locations of herring spawning grounds (see Figure 7 ) in relation to the sedimentary environment in the late-September to early October period $(1964-66,1969,1970)$. Egg beds were restricted to relatively shallow water $(40-50 \mathrm{~m}$ ) where the strongest tidal currents flow over gravel and gravelly sand. Bold lines indicate locations of egg beds in years indicated. Note year-to-year decrease in area occupied by egg beds. Depths in fathoms (meters). Scale 1:275,000 (1 inch $=4.4$ miles). 

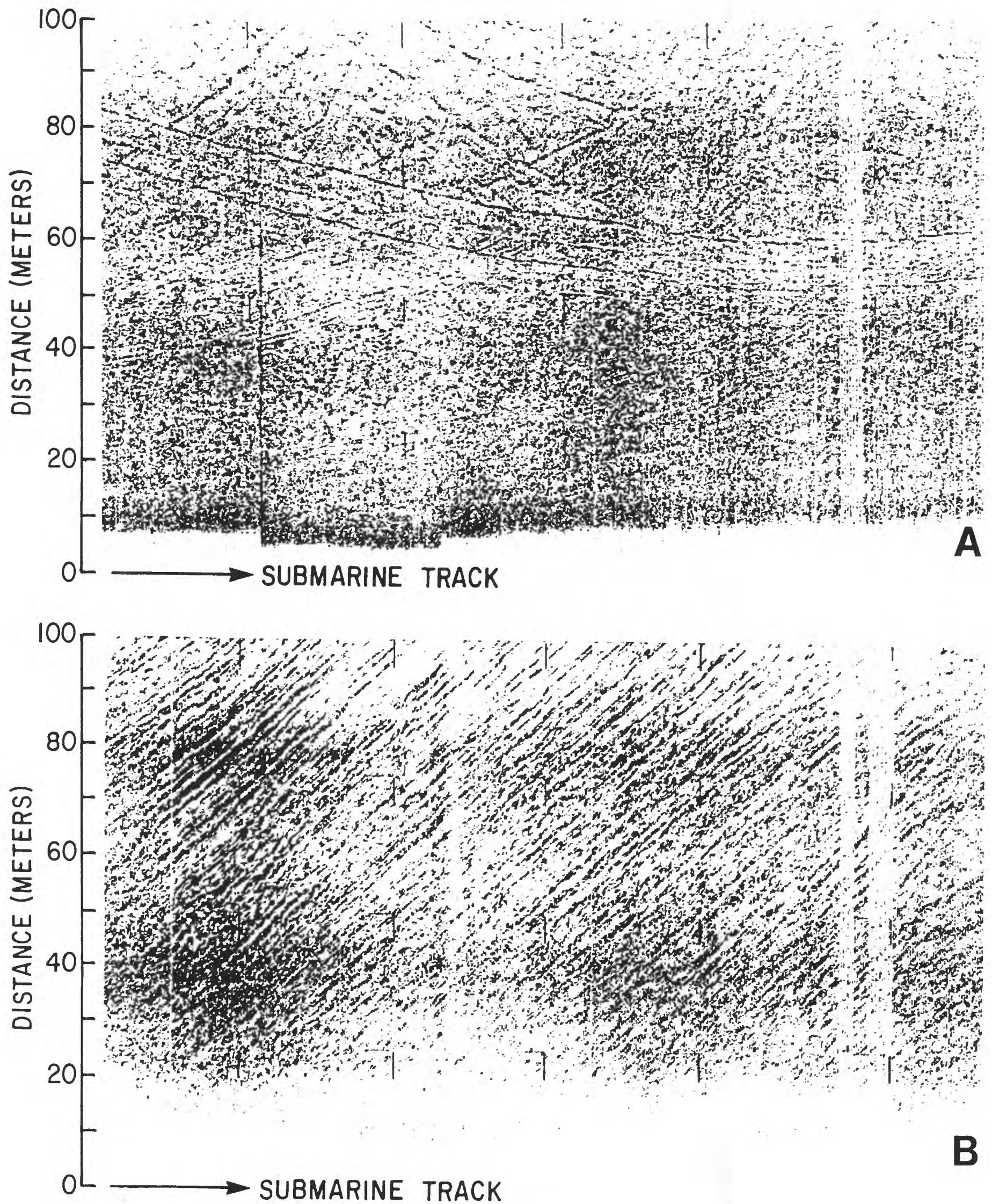
community structure, and on nutrient concentrations within and above the sea bed.

\section{Important Questions for Further Study}

We have shown that the abundance and distribution of several important fisheries species on eastern Georges Bank are related to specific sea floor environments. It is probable that a detailed knowledge of sea bed habitats and the populations that live in them (whether they be permanent or seasonal residents) could provide a basis for marked and rapid improvement in the way the ecosystem is monitored, managed, and studied. Many questions arise from the observations and conclusions made during this and previous investigations of the Georges Bank environment. Partial answers exist to some, but little is known about others. Some of the most important are listed below.

What is the distribution of habitat types, and what are the environmental attributes that distinguish them? In how much detail (at what scale) should they be mapped? How do physical factors such as water depth, topography, current strength, water temperature and chemistry, and availability of sediment types combine to provide an environment that can be utilized successfully by fisheries species, their predators and prey, and their associated fauna? How do species utilize different habitats during different stages of their life cycle or during different seasons? What are their food habits and behavioral traits within their habitats?

How do currents influence the transport patterns of eggs and larvae; and how long do larvae and juveniles remain in the water column before settling out onto the sea bed? What is the distribution of oceanographic fronts that form between water masses, and how much does frontal position vary seasonally and/or annually? How do the physical attributes (temperature, salinity, nutrient concentration, among others) of the water masses on the bank and adjacent to it affect the abundance and distribution of organisms? For example, can the seasonal location of a cold (or warm) water mass on the bank margin affect spawning success or survival of juveniles?

How does habitat alteration by natural processes affect the populations living there? In areas where sand movement is a dominant process on the sea bed, can the rate of formation and movement of sand features be determined and predicted? How does the movement of sand impact other habitats; and for how long? Does an increase in the area of sand bottom favor some species and adversely affect others? Do gravel pavement areas become covered with sand and then later re-emerge to continue their role in the environment? How will the fishery be affected by the inevitable erosion of sand followed by expansion of the gravel pavement; and by the accompanying, long-term deepening of shallow areas of the bank and weakening of bottom currents?

What is the impact of physical disturbance of the sea bed by fishing gear? Does disruption of the sea bed, which damages attached organisms and thereby smoothes

Figure 10. A. Side scan sonograph (left side only) showing disturbed gravel pavement covered with randomlyoriented trawl scars. Location is $42^{\circ} 04^{\prime} \mathrm{N}, 67^{\circ} 14^{\prime} \mathrm{W}$ (in area of Figure 9). Depth $50 \mathrm{~m}$. (U.S. Navy Submarine NR-1, August 31, 1990). B. Side scan sonograph (left side only) showing gravel pavement that is covered with east-west trending trawl scars. Location is $41^{\circ} 54^{\prime} \mathrm{N}, 67^{\circ} 18^{\prime} \mathrm{W}$ (in area of Figure 9). Depth $51 \mathrm{~m}$. (U.S. Navy Submarine NR-1, September 1, 1990). 

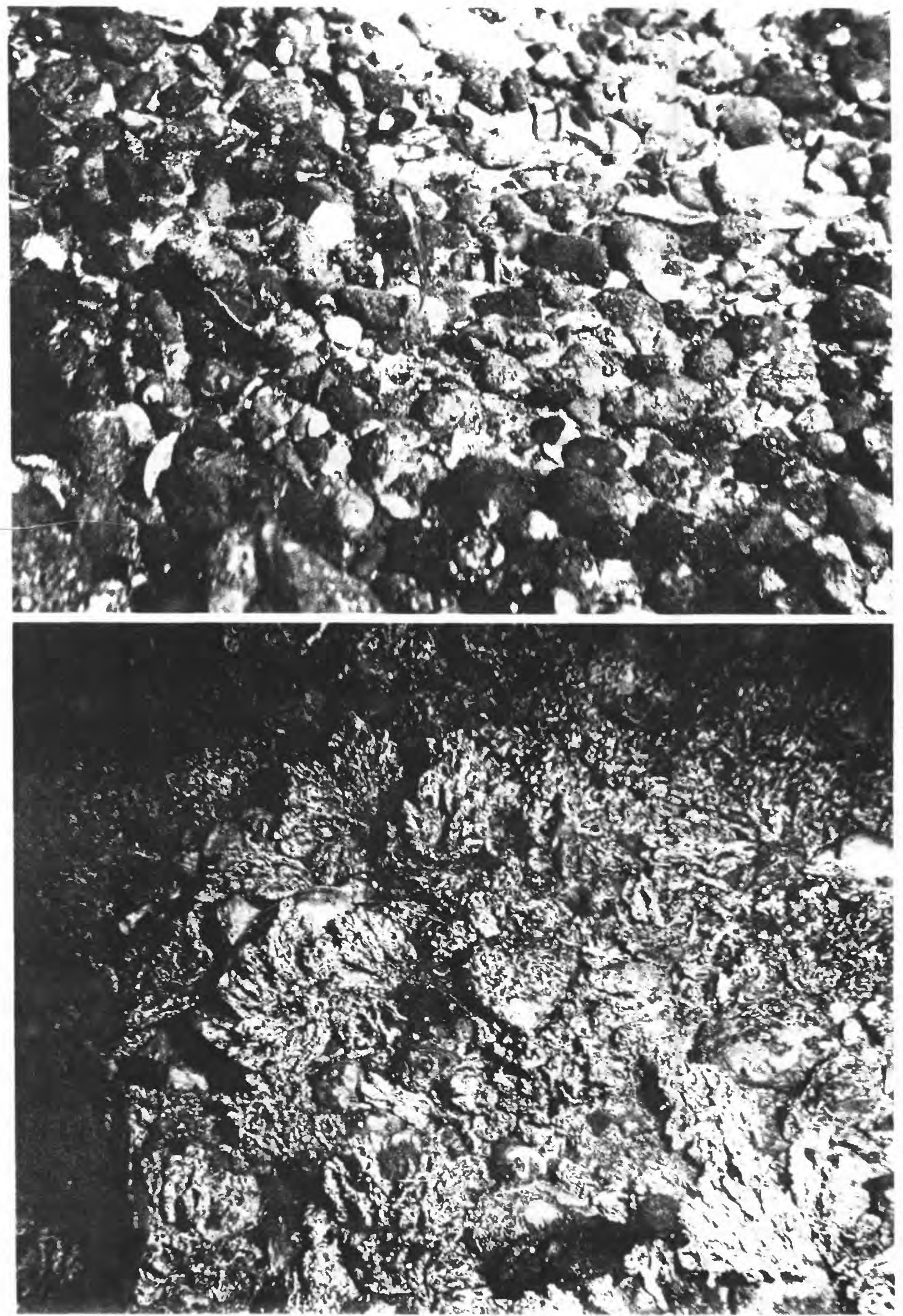

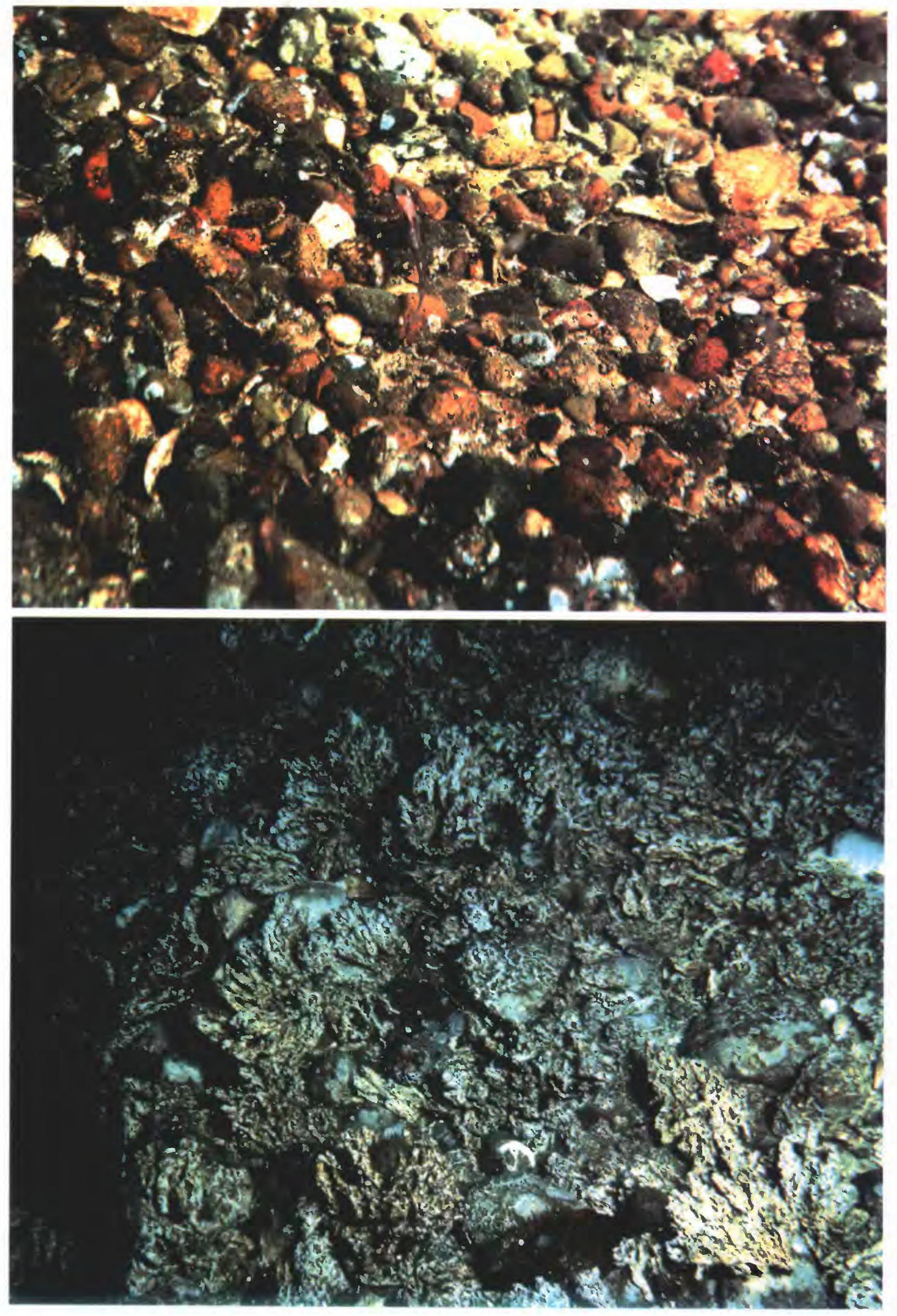
biologially rough habitat, have a positive, negative, or no impact on the fishery? Does this activity oxygenate the sediment, release buried nutrients, damage herring egg beds, or adversely affect juvenile fish and scallops? How long does it take to re-establish a disturbed gravel pavement and its associated fauna? Do untrawled areas of the bank, especially the gravel habitat, serve as refuges for juveniles and for breeding adults that are important in sustaining a heavily utilized fishery? Is eastern Georges Bank a good region in which to compare trawled and untrawled habitats?

Should fisheries sampling strategies be designed to focus on seasonal sampling of specific habitats? Should sampling be more intensive in some habitats than in others? Should sampling strategies emphasize the targeting of individual groundfish species even though this approach may require more sampling effort; or should surveys continue to address all species simultaneously? Should special attention be paid to the sampling of juveniles? Should sampling be designed to take advantage of behavioral traits of species; for example, day versus night sampling?

Answers to these questions will require further multidisciplinary investigations of the Georges Bank environment, a necessary first step being the compilation and interpretation of detailed maps showing relationships between the environment and the fauna in the water column and on the sea bed.

\section{Acknowledgements}

This research was carried out by the U. S. Geological Survey and the National Marine Fisheries Service, in part with the support of NOAA's National Undersea Research Program at the University of Connecticut at Avery Point. We wish to thank Tom Azarovitz and Bill Michaels (NMFS) for providing data on the distribution of sea scallops and juvenile cod. We thank Eric Strom, Carol Brown, and Eric Schmuck (USGS) for assistance with the digital mapping techniques. We also acknowledge with many thanks the support of the captains and crews of the research vessels Seward Johnson and Edwin Link, and the USS Petrel, and the research submersibles Johnson-Sea-Link and Delta, and the U. S. Navy Submarine NR-1.

Figure 11. Photographs of the sea bed on eastern Georges Bank. Top photo, gravel pavement in trawled area; note juvenile cod (dorsal view) in center of photo (water depth $73 \mathrm{~m} ; 42^{\circ} 05^{\prime} \mathrm{N}, 66^{\circ} 40^{\prime} \mathrm{W} ; 1987$ ). Bottom photo, gravel pavement in untrawled area showing abundant worm tubes attached to gravel (water depth $88 \mathrm{~m} ; 42^{\circ} \mathrm{N}$, $\left.66^{\circ} 10^{\prime} W ; 1989\right)$. Pebbles shown here range in size up to $2-3$ inches in length. 


\section{SELECTED REFERENCES}

Anthony, Vaughn, Sauskan, V. I., and Sigaev, J. K., 1970, Cooperative herring egg survey - Georges Bank, 1969: International Commission for the Northwest Atlantic Fisheries, Redbook 1970, Part III, p. 123-133.

Bigelow, H. B., 1927, Physical oceanography of the Gulf of Maine: United States Bureau of Fisheries Bulletin, v. 40, p. 511-1027.

Brooks, D. A., 1985, Vernal circulation in the Gulf of Maine: Journal of Geophysical Research, v. 90, p. 4687-4705.

Brown, W. S., and Moody, J. A., 1987, Tides, in Backus, R. H., ed., Georges Bank: Cambridge, Mass., Massachusetts Institute of Technology Press, p. 100-107.

Butman, Bradford, and Beardsley, R. C., 1987, Physical oceanography, in Backus, R. H., ed., Georges Bank: Cambridge, Mass., Massachusetts Institute of Technology Press, p. 88-98.

Butman, Bradford, Loder, J. W., and Beardsley, R. C., 1987, The seasonal mean circulation: observation and theory, in Backus, R. H., ed., Georges Bank: Cambridge, Mass., Massachusetts Institute of Technology Press, p. 125-138.

Butman, Bradford, Beardsley, R. C., Magnell, B., Frye, D., Vermersch, J. A., Schlitz, R., Limeburner, R., Wright. W. R., and Noble, M., 1982, Recent observations of the mean circulation on Georges Bank: Journal of Physical Oceanography, v. 12, p. 569-591.

Caddy, J. F., 1972, Progressive loss of byssus attachment with size in the sea scallop, Placopecten magellanicus (Gmelin): Journal of Experimental Biology and Ecology, v. 9, p. $179-190$.

Caddy, J. F., and Isles, T. D., 1973, Underwater observations on herring spawning grounds on Georges Bank: International Commission for the Northwest Atlantic Fisheries, ICNAF Research Bulletin No. 10, p. 131-139.

Canadian Hydrographic Service, 1985, Hydrographic chart L/C-8005, 1 sheet, scale $1: 300,000$.

Culliney, J. L., 1974, Larval development of the giant scallop Placopecten magellanicus (Gmelin): Biological Bulletin, v. 147, p. 321-332.

Drapeau, Georges, 1973, Sedimentology of herring spawning grounds on Georges Bank: International Commission for the Northwest Atlantic Fisheries, Research Bulletin No. 10, p. 151-162.

Emery, K. O., 1987, Georges Cape, Georges Island, Georges Bank, in Backus, R. H., ed., Georges Bank: Cambridge, Mass., Massachusetts Institute of Technology Press, p. 38-39. 
Flagg, C. N., 1987, Hydrographic structure and variability, in Backus, R. H., ed., Georges Bank: Cambridge, Mass., Massachusetts Institute of Technology Press, p. 108-124.

Fader, G. B. J., 1984, Geological and geophysical study of Georges Basin, Georges Bank, and the Northeast Channel area of the Gulf of Maine: Geological Survey of Canada Open File 978.

Fader, G. B. J., King, E., Gillespie, R., and King. L. H., 1988, Surficial geology of Georges Bank, Browns Bank, and the southeastern Gulf of Maine: Geological Survey of Canada Open File 1692, 3 sheets, scale 1:300,000.

Garrett, C. J. R., Keeley, J. R., and Greenberg, D. A., 1978, Tidal mixing versus thermal stratification in the Bay of Fundy and Gulf of Maine: Atmosphere-Ocean, v. 16, p. 403423.

Hathaway, J. C., ed., 1971, Data file, Continental Margin Program, Atlantic Coast of the United States, v. 2, Sample collection and analytical data: Woods Hole Oceanographic Institution Reference No. 71-15, 496 p.

Hopkins, T. S., and Garfield, N., 1979, Gulf of Maine Intermediate Water: Journal of Marine Research, v. 37, p. 103-139.

Hopkins, T. S., and Garfield, N., 1981, Physical origins of Georges Bank Water: Journal of Marine Research, v. 39, p. 465-500.

Hughes, T., Borns, H. W., Fastook, J. L., Hyland, M. R., Kite, J. S., and Lowell, T. V., 1985, Models of glacial reconstruction and deglaciation applied to Maritime Canada and New England, in Borns, H. W., LaSalle, P., and Thompson, W. B., eds., Late Pleistocene history of northeastern New England and adjacent Quebec: Geological Society of America Special Paper 197, p. 139-150.

Larsen P. F., and Lee, R. M., 1978, Observations on the abundance, distribution and growth of postlarval sea scallops, Placopecten magellanicus, on Georges Bank: The Nautilus, v. 92, p. 112-116.

Loder, J. W., and Greenberg, D. A., 1986, Predicted positions of tidal fronts in the Gulf of Maine region: Continental Shelf Research, v. 6., p. 397-414.

Lough, R. G., Pennington, M., Bolz, G. R., and Rosenberg, A. A., 1982, Age and growth of larval Atlantic herring, Clupea harengus L., in the Gulf of Maine-Georges Bank region based on otolith growth increments: Fishery Bulletin, v. 80, p. 187-199.

Lough, R. G., Valentine, P. C., Potter, D. C., Auditore, P. J., Bolz, G. R., Neilson, J. D., and Perry, R. I., 1989, Ecology and distribution of juvenile cod and haddock in relation to sediment type and bottom currents on eastern Georges Bank: Marine Ecology Progress Series, v. 56, p. 1-12. 
McKenzie, R. A., 1964, Observations on herring spawning off southwest Nova Scotia: Journal of the Fisheries Research Board of Canada, v. 21, p. 203-204.

Moody, J. A., Butman, B., Beardsley, R. C., Brown, W. S., Daifuku, P., Irish, J. D., Mayer, D. A., Mofjeld, H. O., Petrie, B., Ramp, S., Smith, P., and Wright, W. R., 1984, Atlas of tidal elevation and current observations on the northeast American continental shelf and slope: U. S. Geological Survey Bulletin 1611, 122 p.

National Oceanic and Atmospheric Administration, 1985, Gulf of Maine and Georges Bank: National Ocean Service Chart 13009, 1 sheet, scale 1:500,000.

National Oceanic and Atmospheric Administration, National Marine Fisheries Service, 1991, Status of the fishery resources off the northeastern United States for 1990: National Oceanic and Atmospheric Administration Technical Memorandum NMFS-F/NEC 81, 130 p.

National Oceanic and Atmospheric Administration, National Marine Fisheries Service, 1990, Seasonal distribution patterns of commercial landings of 45 species off the northeastern United States during 1977-88: National Oceanic and Atmospheric Administration Technical Memorandum NFMS-F/NEC-78, $130 \mathrm{p}$.

Noskov, A. S., and Zinkevich, V. N., 1967, Abundance and mortality of herring (Clupea harengus $L$.) on Georges Bank according to the results of eggs calculation in spawning areas in 1964-1966: Intrenational Commission for the Northwest Atlantic Fisheries, ICNAF Research Document 67/98, 16 p.

Pankratov, A. M., and Sigajev, I. K., 1973, Studies on Georges Bank herring spawning in 1970, International Commission for the Northwest Atlantic Fisheries, ICNAF Research Bulletin No. 10. p. 125-129.

Schlee, John, 1973, Atlantic Continental Shelf and Slope of the United States - Sediment texture of the northeastern part: U. S. Geological Survey Professional Paper 529-L, 64 p.

Schlee, John, and Pratt, R. M., 1970, Atlantic Continental Shelf and Slope of the United States - Gravels of the northeastern part: U. S. Geological Survey Professional Paper 529$\mathrm{H}, 39 \mathrm{p}$.

Thouzeau, Gerard, Robert, G., and Smith, S. J., 1991a, Spatial variability in distribution and growth of juvenile and adult sea scallops Placopecten magellanicus (Gmelin) on eastern Georges Bank (northwest Atlantic): Marine Ecology Progress Series, v. 74, 205218.

Thouzeau, Gerard, Robert, G., and Ugarte, R., 1991b, Faunal assemblages of benthic megainvertebrates inhabiting sea scallop groounds from eastern Georges Bank, in relation to environmental factors: Marine Ecology and Progress Series, v. 74, p. 61-82.

Tiboo, S. N., Scarratt, D. J., and McMullon, P. W. G., 1963, An investigation of herring (Clupea harengus L.) spawning using free-diving techniques: Journal of the Fisheries 
Research Board of Canada, v. 20, p. 1067-1079.

Tremblay, M. J., and Sinclair, M. M., 1991, Planktonic sea scallop larvae (Placopecten magellanicus) in the Georges Bank region: broadscale distribution in relation to physical oceanography: Canadian Journal of Fisheries and Aquatic Sciences, in press.

Twichell, D. C., 1983, Bedform distribution and inferred sand transport on Georges Bank, United States Atlantic continental shelf: Sedimentology, v. 30, p. 695-710.

Valentine, P. C., 1991, Sediment texture of eastern Georges Bank - an erosional record of the post-Wisconsinan sea-level rise (abs.): Geological Society of America Abstracts with Programs, v. 23, no. 1, p. 142.

Valentine, P. C., Strom, E. W., and Brown, C. L., 1991a, Maps showing the sea floor topography of eastern Georges Bank: U. S. Geological Survey Miscellaneous

Investigations Series, Map I-2279-A, 1 sheet, scale 1:250,000, in press.

Valentine, P. C., Strom, E. W., Lough, R. G., and Brown, C. L., 1991b, Maps showing the sedimentary environment of eastern Georges Bank: U. S. Geological Survey

Miscellaneous Investigations Series, Map I-2279-B, 1 sheet, scale 1:250,000, in press.

Wigley, R. L., 1961, Bottom sediments of Georges Bank: Journal of Sedimentary

Petrology, v. 31, p. 165-188. 